\title{
A comparison of the effect of xinruibai versus filgrastim on hematopoietic reconstruction after allogeneic hematopoietic stem cell transplantation
}

Qixiang Ye, Hebi Jiang and Hua Jiang ${ }^{*}$ (1)

\begin{abstract}
Background: To compare the effect of xinruibai (Pegfilgrastim) and filgrastim injections on white blood cell and platelet (PLT) recovery, adverse events, post-operative complications, and cost effectiveness after allogeneic hematopoietic stem cell transplantation (allo-HSCT).

Methods: Children who underwent allo-HSCT at our hospital from January 2014 to May 2017 due to thalassemia major, aplastic anemia, leukemia, and mucopolysaccharidosis were included. Among the children, 53 received xinruibai injections and 33 received filgrastim injections.

Results: There were no significant differences in the average time to neutrophil and platelet recovery, the incidence of post-operative complications after allo-HSCT, the number of red blood cell and PLT infusions, or the incidence of adverse events related to the injection between two groups ( $P>0.05$ ). The pain score was 3.06 (SD 0.41) for the xinruibai group and 25.18 (SD 6.22) for the filgrastim group, indicating significant differences between the two groups $(P<0.001)$. No difference was found in the hospitalization cost. The cost of the granulocyte-colony stimulating factor (G-CSF) was $257.11 \pm 61.87$ Euro in the xinruibai group and $214.79 \pm 0.00$ Euro in the filgrastim group, showing significant difference $(P<0.001)$.
\end{abstract}

Conclusions: Xinruibai injection was more convenient, simple, effective, and safer than filgrastim.

Keywords: Pegfilgrastim, Filgrastim, Hematopoietic stem cell transplantation, Hematopoietic reconstruction

\section{Background}

Allogeneic hematopoietic stem cell transplantation (alloHSCT) is an important treatment for hematologic malignancies, metabolic disease, and immunologic deficiency. Granulocyte-colony stimulating factor (G-CSF) infusion can promote hematopoiesis, accelerate reconstruction of the immune system, reduce the duration of febrile neutropenia (FN), decrease the incidence of infections and the number of infusions of blood products, and shorten the hospitalization stay [1-6]. Pegfilgrastim and filgrastim are two common G-CSF injections. Compare with filgrastim,the N-terminal amino acid of pegfilgrastim is

\footnotetext{
* Correspondence: Jiang_Hua33@yeah.net

Department of Hematology and Oncology, Guangzhou Women and
Children's Medical Center, No.9 Jinsui Road, Guangzhou 510623, Guangdong

Department of Hematology and Oncology, Guangzhou Women and
Children's Medical Center, No.9 Jinsui Road, Guangzhou 510623, Guangdong Province, China
}

(c) The Author(s). 2018 Open Access This article is distributed under the terms of the Creative Commons Attribution 4.0 International License (http://creativecommons.org/licenses/by/4.0/), which permits unrestricted use, distribution, and reproduction in any medium, provided you give appropriate credit to the original author(s) and the source, provide a link to the Creative Commons license, and indicate if changes were made. The Creative Commons Public Domain Dedication waiver (http://creativecommons.org/publicdomain/zero/1.0/) applies to the data made available in this article, unless otherwise stated.

linked to a $20 \mathrm{k}$ Dalton, which increases its half-life and reduces the likelihood of being degraded. The clearance of pegfilgrastim is mainly mediated by the rhG-CSF receptor on the surface of neutrophils. As the absolute neutrophil count (ANC) in peripheral blood increases, the plasma level of PEG-rhG-CSF decreases, which gives rise to a self-regulation effect $[7,8]$. It has been shown that pegfilgrastim is comparable to filgrastim in its ability to recruit autologous stem cells for transplantation after chemotherapy for solid tumors and to promote restoration of the immune system and hematopoietic reconstruction [9-13]. In addition, pegfilgrastim has the extra benefits of needing a smaller number of infusions, higher cost effectiveness, and convenient administration. Because of these features, pegfilgrastim is recommended for use by the American Society of Clinical Oncology 
(ASCO) and the European Organization for Research and Treatment of Cancer (EORTC) [14, 15]; however, very few clinical data are available regarding the use of pegfilgrastim after allo-HSCT for non-solid tumors in children. This study was a retrospective analysis comparing pegfilgrastim and filgrastim after allo-HSCT for nonsolid tumors in children.

\section{Methods}

\section{Patients}

A retrospective study design was adopted. Children who received allo-HSCT at our hospital from January 2014 to May 2017 due to thalassemia major, aplastic anemia, leukemia, and mucopolysaccharidosis were included. Pre-treatment was divided into myeloablative and non-myeloablative regimens, and the myeloablative regimen consists of chemotherapy with or without radiotherapy. Among the children, 53 received xinruibai injections and 33 received filgrastim injections randomly. All of the patients underwent primary HSCT. Before the transplantation, the absolute neutrophil count (ANC) was $\geq 1.5 \mathrm{G} / \mathrm{L}$ and the platelet (PLT) count was $\geq 100 \mathrm{G} / \mathrm{L}$ on routine blood testing. The patients received an infusion of $\mathrm{CD}^{+} 4^{+}$cells at a dose $\geq 2.0 \times 10^{6}$. Informed consent was obtained regarding the risk of HSCT and the use of G-CSF.

\section{G-CSF treatment procedures}

xinruibai (xinruibai) was manufactured by Qilu Pharmaceutical (3 mg/bottle; China) and highly consistent with PEG-G-CSF (neulastim) manufactured by Amgen (Roche Scientific Company,USA). Filgrastim ( $75 \mu \mathrm{g} /$ bottle; Kyowa Hakko Kirin Co., Ltd., China) was manufactured using a DNA recombinant technique.

Xinruibai or filgrastim was injected subcutaneously 5 days after HSCT. The dose of a single injection was $100 \mu \mathrm{g} / \mathrm{kg}$ in the xinruibai group and $5 \mu \mathrm{g} / \mathrm{kg} / \mathrm{d}$ in the filgrastim group until the neutrophil count was $\geq 1.0 \mathrm{G} / \mathrm{L}$ for 3 consecutive days or a single neutrophil count $\geq 10$. $0 \mathrm{G} / \mathrm{L}$ plus a PLT count $\geq 20.0 \mathrm{G} / \mathrm{L}$ for 7 consecutive days. This was also the criterion for hematopoietic reconstruction. All patients were followed for at least 3 months. The patients later underwent sex chromosome determination using the FISH technique and/or microsatellite detection using STR-PCR during the course of follow-up to determine the state of the posttransplantation donor cells.

\section{Management and endpoints}

The patients underwent daily routine blood testing (twice weekly after achieving hematopoietic recovery), liver and kidney function testing twice weekly, and quantitative DNA analysis for cytomegalovirus and Epstein-Barr virus after transplantation. Hematopoietic recovery and transplantation-related complications, such as febrile neutropenia (FN), graft-versus-host disease (GVHD), and hemorrhagic cystitis, were observed. $\mathrm{FN}$ was defined as a fever $>38.4{ }^{\circ} \mathrm{C}$ once or $>38.2{ }^{\circ} \mathrm{C}$ on 3 consecutive readings with an $\mathrm{ANC}<0.5 \mathrm{G} / \mathrm{L}$ [16]. The incidence of adverse events (AEs) of G-CSF was compared between the two groups (grade P3 AEs related or unrelated to the study drugs were assessed using NCI-CTCAE [version 3.0]), along with the pain index(A score of 0 indicated no pain, a score of 1-3 indicated mild pain, a score of 4-6 indicated moderate pain, and a score of 7-10 indicated severe pain), cost of G-CSF, and hospitalization cost (total cost from pre-treatment to discharge). Other routine therapies included infusion of blood products. Packed red blood cell and PLT transfusions were administered when hemoglobin $(\mathrm{Hb})$ or PLT levels were $<8 \mathrm{~g} / \mathrm{dL}$ or $<20.0 \mathrm{G} / \mathrm{L}$, respectively. All blood products were irradiated and filtered prior to infusion [17]. Antibiotics and antiviral drugs were given depending on the conditions of the patient. During this study period the guidelines for supportive therapies adopted by the transplant team did not vary.

\section{Statistical analyses}

All statistical analyses were performed using SPSS 19. 0 software. Date obeying a normal distribution or quasi-normal distribution were described by \pm s. Data not obeying a normal distribution were described by $\mathrm{M}(\mathrm{QR})$. Intergroup comparisons of means, medians, and categorical variables were performed using t-tests, Mann-Whitney $U$ tests, and $x^{2}$ tests, respectively.

Table 1 Baseline clinical features of patients

\begin{tabular}{|c|c|c|c|c|}
\hline Variable & $\begin{array}{l}\text { xinruibai group } \\
(N=53)\end{array}$ & $\begin{array}{l}\text { Filgrastim group } \\
(N=33)\end{array}$ & $\begin{array}{l}\mathrm{t} / \mathrm{x}^{2} \\
\text { value }\end{array}$ & $\begin{array}{l}P \\
\text { value }\end{array}$ \\
\hline Age & $6.26 \pm 3.05$ & $7.30 \pm 3.27$ & 1.46 & 0.1467 \\
\hline Gender n (\%) & & & 0.16 & 0.681 \\
\hline Male & $35(66.0)$ & $24(72.7)$ & & \\
\hline Female & $18(34.0)$ & $9(27.3)$ & & \\
\hline Disease n (\%) & & & 2.54 & 0.198 \\
\hline Aplastic anemia & $2(3.8)$ & $3(9.1)$ & & \\
\hline Leukemia & $2(3.8)$ & $6(18.1)$ & & \\
\hline Thalassemia major & $46(86.8)$ & $24(72.7)$ & & \\
\hline Mucopolysaccharidosis & $3(5.7)$ & $0(0.0)$ & & \\
\hline $\begin{array}{l}\text { Pre-treatment } \\
\text { scheme } \mathrm{n}(\%)\end{array}$ & & & 2.01 & 0.215 \\
\hline $\mathrm{BU}+\mathrm{CTX}+\mathrm{ATG}$ & $4(7.5)$ & $4(12.1)$ & & \\
\hline$C T X+A T G+T B I$ & $1(1.9)$ & $2(6.1)$ & & \\
\hline $\mathrm{FLU}+\mathrm{CTX}+\mathrm{ATG}$ & $48(90.6)$ & $27(81.8)$ & & \\
\hline $\begin{array}{l}\text { Number of infused } \\
\text { CD34 + cells }\end{array}$ & $6.19 \pm 2.31$ & $5.26 \pm 1.95$ & 1.92 & 0.051 \\
\hline
\end{tabular}


Table 2 Comparison of efficacy between the xinruibai and filgrastim groups

\begin{tabular}{lllll}
\hline Indicator & xinruibai group & Filgrastim group & $t$ value & $P$ value \\
\hline $\begin{array}{l}\text { Time to neutrophil } \\
\text { recovery (d) }\end{array}$ & $13.18(2.87)$ & $13.42(2.31)$ & 0.42 & 0.673 \\
$\begin{array}{l}\text { Time to platelet } \\
\text { recovery (d) }\end{array}$ & $12.92(4.05)$ & $13.82(5.52)$ & 0.81 & 0.390 \\
$\begin{array}{l}\text { White blood } \\
\text { cell count }\end{array}$ & $2.58(1.48)$ & $2.64(1.58)$ & 0.18 & 0.854 \\
$\begin{array}{l}\text { Neutrophil } \\
\text { percentage }\end{array}$ & $75.66(9.31)$ & $72.15(11.69)$ & 1.45 & 0.150 \\
\hline
\end{tabular}

\section{Result}

\section{Baseline clinical features}

The two groups of patients had no significant differences in constitution, age, gender, body weight, pre-treatment, and number of infused CD $34^{+}$cells (Table 1 ).

\section{Hematopoietic reconstruction}

The average time to neutrophil recovery was $13.42 \mathrm{~d}$ (SD 2.31) in the filgrastim group and $13.18 \mathrm{~d}$ in the xinruibai group. The average time to PLT recovery was 13.82 $\mathrm{d}$ (SD 5.52) in the filgrastim group and $12.92 \mathrm{~d}$ (SD 4.05) in the xinruibai group. The white blood cell count and neutrophil count in the filgrastim group was $2.64 \mathrm{G} / \mathrm{L}$ (SD 1.58 ) and $72.15 \%$ (SD 11.69), respectively, and $2.58 \mathrm{G} / \mathrm{L}$ (SD 1.48) and 75.66\% (SD 9.13) in the xinruibai group, respectively; there were no significant differences between the two groups (Table 2). A comparison of the median time to neutrophil recovery between the two groups was not significantly different (Fig. $1 ; P=0.633$ ). A comparison of the median time to PLT recovery between the two groups also indicated no significant difference (Fig. $2 ; P=$ 0.911). It seems that different conditioning regimens they used had no significant influence in the time of peripheral hematopoietic cell reconstitution.

\section{Drug-related adverse events and complications}

The common adverse events related to G-CSF include fevers, skin rashes, arthralgias, ostealgia and diarrhea. Only mild AEs were observed in the two groups, and none of the patients had AEs of grade 3 or above.

Post-transplantation complications include fevers for unknown reasons, FN, infections caused by specified pathogens, GVHD, and hemorrhagic cystitis. The two groups had no significant differences in the incidence of fever for unknown reasons and transplantation-related complications (Table 3).

\section{Comparison of pain score between the two groups}

A single subcutaneous xinruibai injection was required, while serial filgrastim infusions were administered. Pain was scored using the modified Flacc scale for infants and the VAS scale [18-21]. Using this criterion, the pain score was 3.06 for the xinruibai group (SD 0.41) and 25.18 for the filgrastim group (SD 6.22), which indicated significant difference between the two groups $(P<0.001$; Fig. 3$)$.

\section{G-CSF and total hospitalization costs}

The cost of one xinruibai and filgrastim injection $(75 \mu \mathrm{g})$ was 214.79 Euro and 26.27 Euro, respectively. To

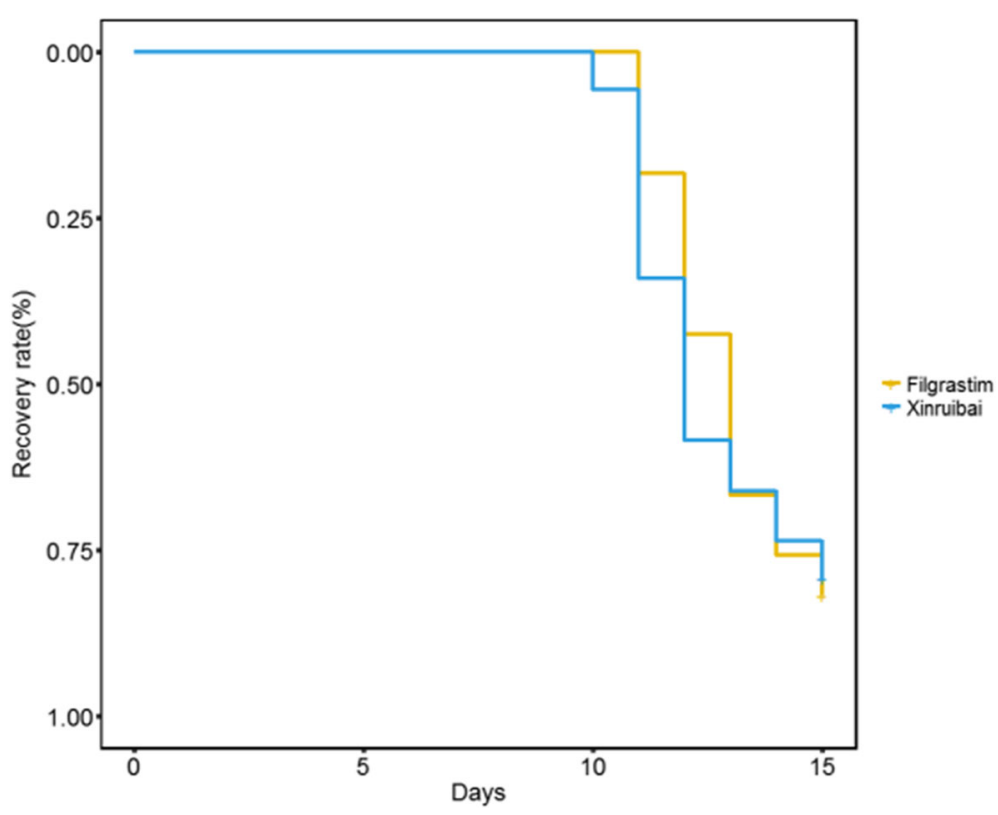

Fig. 1 Comparison of time to neutrophil recovery between the two groups 


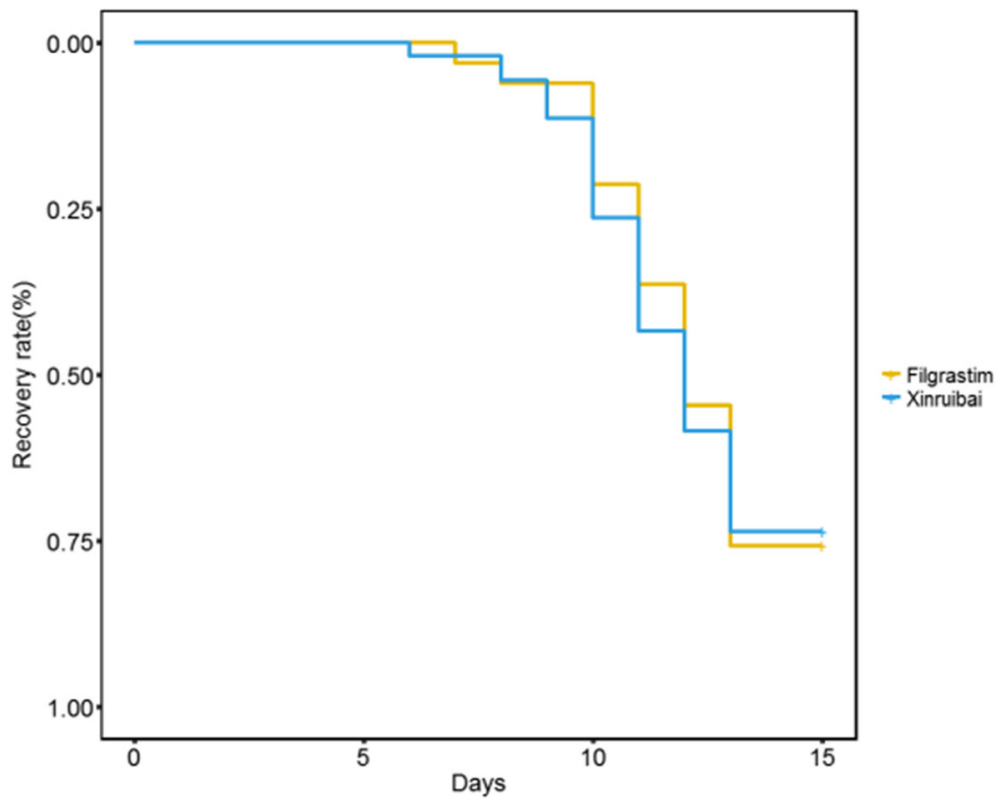

Fig. 2 Comparison of time to platelet recovery between the two groups

achieve hematopoietic reconstruction, an average of 9.78 injections (SD 2.36) of filgrastim were needed, which cost $257.11 \pm 61.87$ Euro. There was a significant difference compared with the xinruibai group (Table 4). The total hospitalization cost of the xinruibai group was $26,949.77 \pm 11,600.97$ Euro, which was lower than the filgrastim group, but not statistically significant (Fig. 4).

\section{Discussion and conclusions}

The use of G-CSF after HSCT can promote hematopoietic and immune system reconstruction, while reducing the duration of FN and the incidence of infections, thereby shortening the hospital stay and lowering the total costs $[14,15]$. Because of the longer half-life, only a single dose of xinruibai is needed, and the efficacy has been confirmed to be comparable to that of 10-11 injections of filgrastim during each cycle of

Table 3 Comparison of the incidence of post-transplantation complications between the two groups (case, percentage)

\begin{tabular}{lllll}
\hline Indicator & $\begin{array}{l}\text { xinruibai } \\
\text { group }\end{array}$ & $\begin{array}{l}\text { Filgrastim } \\
\text { group }\end{array}$ & $X^{2}$ & $P$ value \\
\hline $\begin{array}{l}\text { Fever for unknown } \\
\text { reason (UFO) } \\
\quad \text { Yes }\end{array}$ & $32(60.38)$ & $20(60.61)$ & 0.0004 & $>0.05$ \\
$\quad$ No & $21(39.62)$ & $13(39.39)$ & & \\
$\begin{array}{l}\text { Transplantation-related } \\
\text { complications }\end{array}$ & & & 0.8347 & $>0.05$ \\
$\quad$ Yes & $10(18.87)$ & $9(37.5)$ & & \\
$\quad$ No & $43(81.13)$ & $24(62.5)$ & & \\
\hline
\end{tabular}

chemotherapy [22-26]. The efficacy of xinruibai is considered comparable to that of filgrastim during chemotherapy for tumors in adults and solid tumors in children or after HSCT for lymphoma and multiple myeloma. Several guidelines have already recommended the use of xinruibai; however, as far as we know, the clinical trials on the use of xinruibai after HSCT for non-solid tumors in children are deficient.

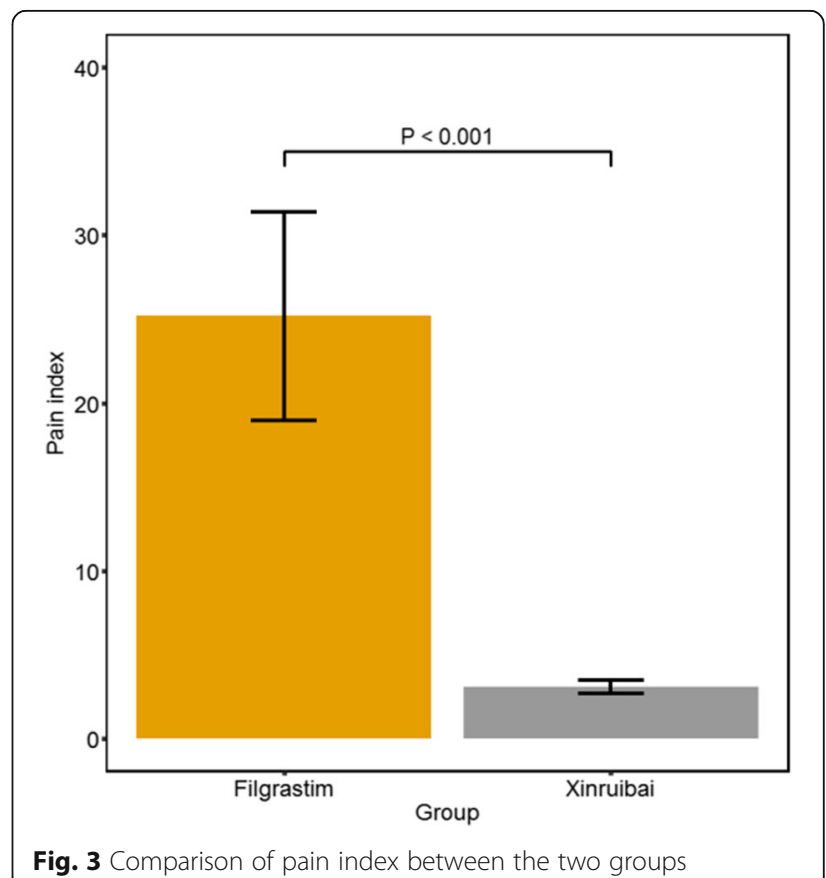


Table 4 Comparison of expenses between the two groups ( $\bar{x}$ \pm SD, Euro)

\begin{tabular}{llll}
\hline Indicator & xinruibai group & Filgrastim group & $P$ value \\
\hline $\begin{array}{l}\text { Expenses } \\
\text { of GCFS }\end{array}$ & $214.79 \pm 0.00$ & $257.11 \pm 61.87$ & $<0.001$ \\
injection & & & \\
Total hospitalization cost & $26,949.77 \pm$ & $28,930.52 \pm$ & $>0.05$ \\
& $11,600.97$ & $11,973.67$ & \\
\hline
\end{tabular}

It has been shown that the optimal duration of G-CSF is 4-7 days during chemotherapy for lymphoma [27]. According to previous studies, we performed a G-CSF infusion starting from the 5th day after HSCT. Although some studies have proposed an earlier start time for GCSF infusions, other studies have suggested that the delayed use of G-CSF produces no apparent influence on neutrophil recovery and transplantation [28, 29]. Thus far, there have been no large-scale randomized trials indicating that xinruibai outperforms filgrastim in accelerating hematopoietic reconstruction after allo-HSCT or in shortening the time to recovery from $\mathrm{FN}$ after chemotherapy [9-13]; however, one meta-analysis has shown that xinruibai can more effectively reduce the incidence of FN and accelerate neutrophil recovery after alloHSCT than filgrastim, and the former has a higher cost effectiveness [22-25, 30, 31].We conducted this retrospective study that compared the efficacy of xinruibai and filgrastim in promoting hematopoietic reconstruction after allo-HSCT for thalassemia major, aplastic anemia, leukemia, and mucopolysaccharidosis.

The efficacy of xinruibai and filgrastim was compared for different diseases under different pre-treatment regimens by analyzing the indicators of hematopoietic reconstruction and incidence of FN.

Our results indicated that compared with several injections of filgrastim, a single dose of xinruibai showed comparable efficacy in promoting hematopoietic and immune system reconstruction (neutrophil recovery) and reducing post-transplantation complications. This finding was in agreement with previous studies involving lymphoma, leukemia, and solid tumors in children [9-13]. Moreover, the total hospitalization cost in the xinruibai group was lower than the filgrastim group, but not a statistically significant difference. This finding may be due to the small sample size of our study. The cost of G-CSF was lower in the xinruibai group than the filgrastim group, which indicated that xinruibai has a higher cost effectiveness, as has been reported by Gerds et al. [31, 32].

The additional benefits of xinruibai may be associated with the up-regulation of transcription factors, such as HOXA9 and GATA3, which leads to more extensive progenitor cell differentiation and colonization [33]. It is therefore proposed that xinruibai also has an impact on the number of lymphocytes and reconstruction of the immune system after HSCT; however, no definitive conclusions have been reached given the small sample size and heterogeneity of the diseases included $[34,35]$.

We also paid attention to the psychological impact of several infusions of filgrastim. As analyzed above, several infusions of filgrastim increased the pain score and psychological burden for both children and their parents, thereby reducing compliance. Moreover, several infusions of filgrastim also increased the work burden for the medical staff. Xinruibai is favored in terms of cost effectiveness and convenience for the patients and medical staff.

Biases are inevitable for a retrospective cohort study, but the research has encouraging findings. Our data suggest that xinruibai and filgrastim were not significantly different in promoting hematopoietic reconstruction after allo-HSCT and preventing complications; however, xinruibai injection was more convenient, simple, effective, and safer than filgrastim. Therefore, xinruibai

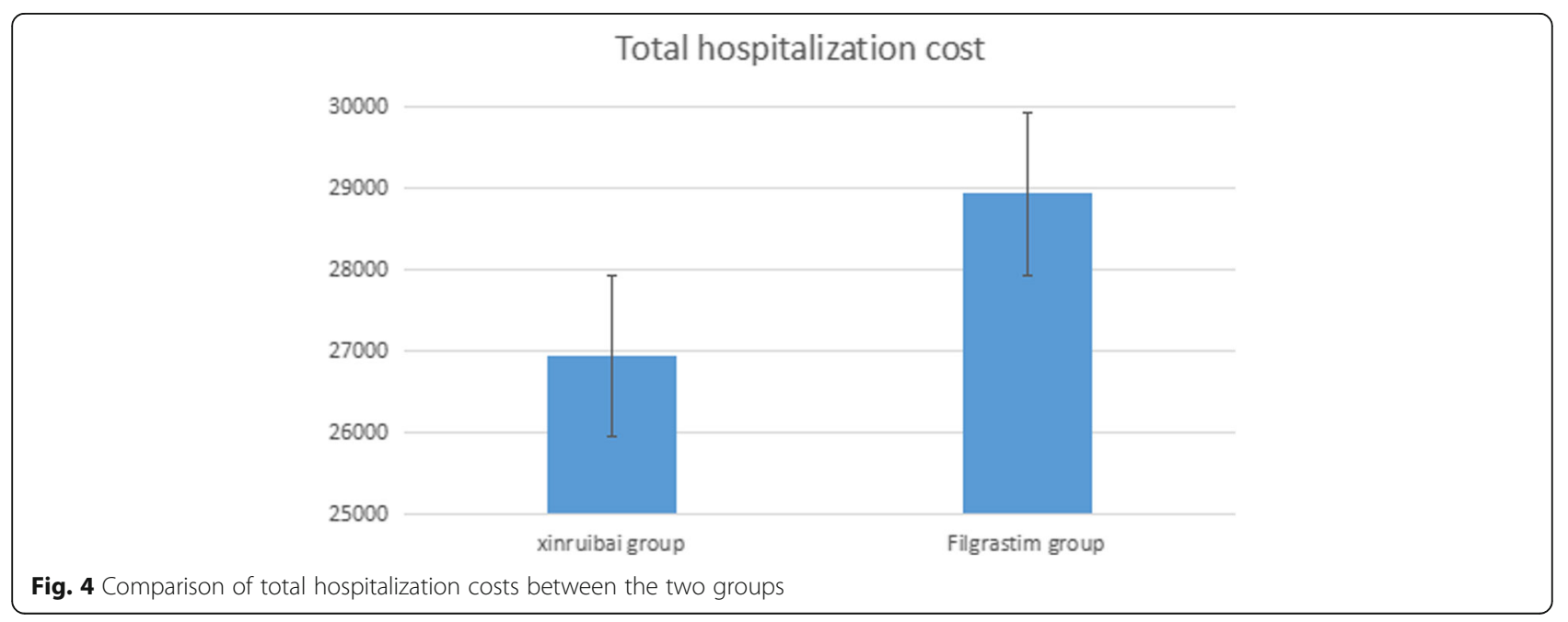


positions in a higher cost- effectiveness plane. But multicenter randomized controlled trials with a larger sample size are needed to confirm the findings. The long-term effect of xinruibai versus filgrastim on hematopoietic and immune system reconstruction and on the posttransplantation complications, such as GVHD are also needed to further investigation.

\section{Abbreviations}

AEs: Adverse events; allo-HSCT: Allogeneic hematopoietic stem cell transplantation; ANC: Absolute neutrophil count; ASCO: American Society of Clinical Oncology; EORTC: Research and Treatment of Cancer; FN: Febrile neutropenia; G-CSF: Granulocyte-colony stimulating factor; GVHD: Graftversus-host disease; Hb: Hemoglobin; PEG: Polyethylene glycol; PLT: Platelet

\section{Acknowledgements}

Not applicable.

\section{Funding}

None.

Availability of data and materials

Not applicable.

\section{Authors' contributions}

$\mathrm{HJ}$ is resposible for the concept and design and approval of article; QY is resposible for the data analysis/interpretation, literature research, manuscript preparation, editing and review; $\mathrm{HJ}$ is resposible for clinical studies experimental studies and data collection. All authors read and approved the final manuscript.

\section{Ethics approval and consent to participate}

The study was approved by the ethic committee. Informed consent was obtained.

\section{Consent for publication}

Not applicable

\section{Competing interests}

The authors declare that they have no competing interests.

\section{Publisher's Note}

Springer Nature remains neutral with regard to jurisdictional claims in published maps and institutional affiliations.

Received: 26 November 2017 Accepted: 21 March 2018 Published online: 31 May 2018

\section{References}

1. Spitzer G, Adkins DR, Spencer V, Dunphy FR, Petruska PJ, Velasquez WS, et al. Randomized study of growth factors post-peripheral-blood stem-cell transplant: neutrophil recovery is improved with modest clinical benefit. J Clin Oncol. 1994;12:661-70.

2. Klumpp TR, Mangan KF, Goldberg SL, Pearlman ES, Macdonald JS. Granulocyte colony-stimulating factor accelerates neutrophil engraftment following peripheral-blood stemcell transplantation: a prospective, randomized trial. J Clin Oncol. 1995;13:1323-7.

3. McQuaker IG, Hunter AE, Pacey S, Haynes AP, labal A, Russell NH. Low-dose filgrastim significantly enhances neutrophil recovery following autologous peripheral-blood stem-cell transplantation in patients with lymphoproliferative disorders: evidence for clinical and economic benefit. . Clin Oncol. 1997;15:451-7.

4. Tarella C, Castellino C, Locatelli F, Caracciolo D, Corradini P, Falda M, et al. G-CSF administration following peripheral blood progenitor cell (PBPC) autograft in lymphoid malignancies: evidence for clinical benefits and reduction of treatment costs. Bone Marrow Transplant. 1998;21:401-7.

5. Linch DC, Milligan DW, Winfield DA, Kelsey SM, Johnson SA, Littlewood TJ, et al. G-CSF after peripheral blood stem cell transplantation in lymphoma patients significantly accelerated neutrophil recovery and shortened time in hospital: results of a randomized BNLI trial. Br J Haematol. 1997;99:933-8.
6. Hornedo J, Sola C, Solano C, López JJ, Alonso S, Lluch A, et al. The role of granulocyte colony-stimulating factor (G-CSF) in the post-transplant period. Bone Marrow Transplant. 2002;29:737-43.

7. Molineux G, Kinstler O, Briddell B, Hartley C, McElroy P, Kerzic P, et al. A new form of filgrastim with sustained duration in vivo and enhanced ability to mobilize PBPC in both mice and humans. Exp Hematol. 1999; 27:1724-34

8. Molineux G. Pegfilgrastim: using pegylation technology to improve neutropenia support in cancer patients. Anti-Cancer Drugs. 2003;14:259-64.

9. Jagasia MH, Greer JP, Morgan DS, et al. Xinruibai after highdose chemotherapy and autologous peripheral blood stem cell transplant: phase II study. Bone Marrow Transplant. 2005;35:1165-9.

10. Staber PB, Holub R, Linkesch W, Schmidt $H$, Neumeister P. Fixed-dose single administration of pegfilgrastim vs daily filgrastim in patients with haematological malignancies undergoing autologous peripheral blood stem cell transplantation. Bone Marrow Transplant. 2005;35:889-93.

11. Vanstraelen G, Frere P, Ngirabacu MC, Willems E, Fillet G, Beguin Y. Pegfilgrastim compared with filgrastim after autologous hematopoietic peripheral blood stem cell transplantation. Exp Hematol. 2006;34:382-8.

12. Fenk R, Hieronimus N, Steidl U, Bruns I, Graef T, Zohren F, et al. Sustained G-CSF plasma levels following administration of pegfilgrastim fasten neutrophil reconstitution after high-dose chemotherapy and autologous blood stem cell transplantation in patients with multiple myeloma. Exp Hematol. 2006;34:1296-302.

13. Ballestrero A, Boy D, Gonella R, Miglino M, Clavio M, Barbero V, et al. Pegfilgrastim compared with filgrastim after autologous peripheral blood stem cell transplantation in patients with solid tumours and lymphomas. Ann Hematol. 2008:87:49-55.

14. Smith TJ, Khatcheressian J, Lyman GH, Ozer H, Armitage JO, Balducci L, et al. 2006 update of recommendations for the use of white blood cell growth factors: an evidence-based clinical practice guideline. J Clin Oncol. 2006:24:3187-205.

15. Aapro MS, Bohlius J, Cameron DA, Dal Lago L, Donnelly JP, Kearney N, et al. 2010 update of EORTC guidelines for the use of granulocyte-colony stimulating factor to reduce the incidence of chemotherapy-induced febrile neutropenia in adult patients with lymphoproliferative disorders and solid tumours. Eur J Cancer. 2011;47:8-32.

16. Freifeld AG, Bow EJ, Sepkowitz KA, Boeckh MJ, Ito Jl, Mullen CA, et al. Clinical practice guideline for the use of antimicrobial agents in neutropenic patients with cancer: 2010 update by the infectious diseases society of america. Clin Infect Dis. 2011;52(4):427-31.

17. Dwyre DM, Holland PV. Transfusion-associated graft-versushost disease. Vox Sang. 2008;95:85-93.

18. Merkel SL, Vepel-Lewis T, ShayeVtiz JR, Malviya S. The FLACC:a behaviora scale for scoring postoperative pain in young children. Pediatr Nurs. 1997;3:293-7.

19. Wewers ME, Lowe NK. A critical review of visual analogue scales in the measurement of clinical phenomena. Res Nurs Healthm. 1990:13:227-36.

20. Figueiredo RR, Azevedo AA, OliVeira Pde M. Correlation analysis of the visual-analogue scale and the tinnitus handicap inventory in tinnitus patients. Braz J otorhinolaryngol. 2009;75:76-9.

21. Kimura T, Hayashida K, Araki Y, Morita T, Yamaguchi N, Eboshida A. How valid is the self-administered visual analogue scale tor assessing the health status of elderly people? Hiroshima J Med Sci. 2008:57:85-92.

22. Green MD, Koelbl H, Baselga J, Galid A, Guillem V, Gascon P, et al. A randomized double-blind multicenter phase III study of fixed-dose singleadministration pegfilgrastim versus daily filgrastim in patients receiving myelosuppressive chemotherapy. Ann Oncol. 2003;14(1):29-35.

23. Grigg A, Solal-Celigny P, Hoskin P, Taylor K, McMillan A, Forstpointner R, et al. Open-label, randomized study of pegfilgrastim vs. daily filgrastim as an adjunct to chemotherapy in elderly patients with non-Hodgkin's lymphoma. Leuk Lymphoma. 2003;44(9):1503-8.

24. Holmes FA, Jones SE, O'Shaughnessy J, Vukelja S, George T, Savin M, et al. Comparable efficacy and safety profiles of once-per-cycle pegfilgrastim and daily injection filgrastim in chemotherapyinduced neutropenia: a multicenter dose-finding study in women with breast cancer. Ann Oncol. 2002;13(6):903-9.

25. Holmes FA, O'Shaughnessy JA, Vukelja S, Jones SE, Shogan J, Savin M, et al. Blinded, randomized, multicenter study to evaluate single administration pegfilgrastim once per cycle versus daily filgrastim as an adjunct to chemotherapy in patients with high-risk stage II or stage III/IV breast cancer. J Clin Oncol. 2002;20(3):727-31. 
26. Vose JM, Crump M, Lazarus H, Emmanouilides C, Schenkein D, Moore J, et al. Randomized, multicenter, open-label study of pegfilgrastim compared with daily filgrastim after chemotherapy for lymphoma. J Clin Oncol. 2003; 21(3):514-9.

27. Zeynalova S, Ziepert M, Scholz M, Schirm S, Zwick C, Pfreundschuh M, et al. Comparison and modelling of pegylated or unpegylated G-CSF schedules in CHOP-14 regimen of elderly patients with aggressive B-cell lymphoma. Ann Hematol. 2013;92:1641-52.

28. Faucher C, Le Corroller AG, Chabannon C, Novakovitch G, Manonni P, Moatti JP, et al. Administration of G-CSF can be delayed after transplantation of autologous G-CSF-primed blood stem cells: a randomized study. Bone Marrow Transplant. 1996;17:533-6.

29. de Azevedo AM, Nucci M, Maiolino A, Vigorito AC, Simoes BP, Aranha FJ, et al. A randomized,multicenter study of G-CSF starting on day +1 vs day +5 after autologous peripheral blood progenitor cell transplantation. Bone Marrow Transplant. 2002;29:745-51.

30. Ziakas PD, Kourbeti IS. Pegfilgrastim vs. filgrastim for supportive care after autologous stem cell transplantation: can we decide? Clin Transpl. 2012;26:16-22.

31. Gerds A, Fox-Geiman M, Dawravoo K, Rodriguez T, Toor A, Smith S, et al. Randomized phase III trial of pegfilgrastim versus filgrastim after autologus peripheral blood stem cell transplantation. Biol Blood Marrow Transplant. 2010;16:678-85.

32. Sebban C, Lefranc A, Perrier L, Moreau P, Espinouse D, Schmidt A, et al. A randomised phase II study of the efficacy, safety and cost-effectiveness of pegfilgrastim and filgrastim after autologous stem cell transplant for lymphoma and myeloma (PALM study). Eur J Cancer. 2012;48:713-20.

33. Bruns I, Steidl U, Fischer JC, Czibere A, Kobbe G, Raschke S, et al. Pegylated granulocyte colony-stimulating factor mobilizes CD341 cells with different stem and progenitor subsets and distinct functional properties in comparison with unconjugated granulocyte colony-stimulating factor. Haematologica. 2008;93:347-55.

34. Porrata LF, Litzow MR, Tefferi A, Letendre L, Kumar S, Geyer SM, Markovic $\mathrm{SN}$. Early lymphocyte recovery is a predictive factor for prolonged survival after autologous hematopoietic stem cell transplantation for acute myelogenous leukemia. Leukemia. 2002;16:1311-8.

35. Porrata LF, Gertz MA, Inwards DJ, Litzow MR, Lacy MQ, Tefferi A, et al. Early lymphocyte recovery predicts superior survival after autologous hematopoietic stem cell transplantation in multiple myeloma or nonHodgkin lymphoma. Blood. 2001;98:579-85.

\section{Submit your next manuscript to BioMed Central and we will help you at every step:}

- We accept pre-submission inquiries

- Our selector tool helps you to find the most relevant journal

- We provide round the clock customer support

- Convenient online submission

- Thorough peer review

- Inclusion in PubMed and all major indexing services

- Maximum visibility for your research

Submit your manuscript at www biomedcentral.com/submit

) Biomed Central 